\title{
INVESTIGATING THE IMPACT OF RETAIL OUTLET ATTRIBUTES ON RETAIL PATRONAGE
}

\author{
Joseph Frempong ${ }^{1 *}$, Edward Markwei Martey ${ }^{2}$ \\ *1Koforidua Polytechnic, Ghana, Kfrempy1@gmail.com \\ ${ }^{2}$ Sumy Agrarian University, Sumy.Ukraine edmarkwei@yahoo.com
}

*Corresponding Author: -

Email: Kfrempy1@gmail.com

\begin{abstract}
The purpose of this study is to investigate the impact of retail outlets attributes on retail patronage in Ghana; the main objective is to study outlet attributes that are requisite to attract patronage. Two hundred and nine (309) questionnaires were returned, out of five hundred (500) questionnaires distributed through convenience sampling method to the population. With the aid of Statistical Package for Social Sciences (SPSS) the following statistics were employed: descriptive statistics, cranach's alpha, kurtosis and skewness and Chi-square analysis was used to measure the impact of attributes (price, service quality, customer satisfaction, and brand image) on dependent variable (customer loyalty). The findings revealed that all four construct of customer retention; namely price, service quality, customer satisfaction, and brand image had a significant and positive relationship with customer loyalty. The research suggests that Customer Relationship Managers (CRMs) finds out what customers expect and serve them better and solve all customers' complaints on time.
\end{abstract}

Keywords: price; service quality; customer satisfaction; brand image; customer loyalty

\section{(c) $(\$)$}




\title{
INTRODUCTION
}

The emerging economy in Ghana has led to unprecedented level of economic expansion which has translated into breeding of numbers of retail stores across the country. The pattern of growth in the retail industry is as a result of changes in domestic geographic, demographic, psychographic, increasing urbanization, advancement in technological which has created opportunity for the development of retailing in Ghana. Besides, tremendous change in lifestyle, increased rate of literacy, growing number of working women, excess migration to the urban centers, increased of purchasing power, media advertising has all contributed to growth in the retail sector of Ghana.

Retailing offers very wide ranges and categories of product and services. Some specialize in food and grocery, footwear, cosmetics, dresses, home appliance and others. Many of the retail stores provide almost the same goods and services. Therefore, to differentiate one from the other, customer must be assured of high quality, differences in price, variety of products to select from and friendly atmosphere, ambience, accessibility to customers and customer service support. Customer patronage plays a vital role of the existence of any retail store. This brings the need to study consumer buying behavior in the retail industry. So many factors lead to buying from a retail outlet. this can be categorized into two groups into, internal and external. Existing customers generate larger margins and profits (per customer) than the new ones (Smith and Taylor, 2005).

\section{Literature review}

Previous research has identified store attributes as multi-dimensional construct including location of store, nature and quality of stocks, in-store promotions, sales personnel, physical attribute, and convenience of store, atmospherics and loyalty cards that influence consumer attitude or behavior (Miranda, Konya \& Havrila, 2005).Similarly, in another study, Yilmaz et al., (2007) found other constructs; the location of the shopping mall, product, price and quality, physical appearance, attitude of store staff were important factors shaping customer outlet selection preferences. A recent study by Kursunluoglu (2014) establishes 5 criteria that affect consumers' retail store choices as; reliability; short waiting period on check-out lines; correctness of the price tags on the shelves; broad merchandise assortment, and; impressive in-store atmosphere. Besides, a study conducted by Batt (2009) on Australian consumers ranked influencers of retail outlet choice as follows; competitive price; good quality products; freshness; convenience; close proximity to home and; location. While, a study based on Malaysian consumers by Wel, Husssain, Omar and nor (2012) classified influences as follows; store personnel and physical characteristics; adversity by the store; store merchandise selection; store location; peer influence; product variety and quality; services offered by the store. In a study carried out by Oghojafor, et al (2012) to determine outlet attributes that induce Nigerian women's preference. The study found that, the attributes were quality, price, and location of outlet, cleanliness, product assortment, pricing method, and availability of parking space. After comparing the construct, dimensions and criteria of factors that influences retail outlet choice, from the reviewed related literature, the researcher settled on the following construct: Assortment, Atmosphere, and Location, Image and Price for the study.

\section{Assortment}

A retail store which is a one stop shop for many classes and kinds of goods and services, in many at times enjoy mass patronage. This is because, customer want at store were all their needs can be met under one umbrella. Solgaard and Hansen (2003), assortment was found to be the single most important driver for the choice between store formats; price level and distance also being important drivers for consumers'choice between store formats; although quality and service were not found to be differentiator between formats. Shoppers were less willing to tradeoff location convenience or, in some cases, quality and assortment (Seiders et al., 2000)

\begin{abstract}
Atmosphere
Store atmosphere is the ambience and design of a retail store. This intent influence customer preference and shopping experience (Baker et al., 2002; Thang \& Tan, 2003). According to Paulins and Geistfeld (2003) the key reason why stores are considered desirable is the atmosphere it exist and it influences appealing merchandise selection. Store convenience and customer services positively influence customers' supermarket choices, whilst, entertainment, parking and ambience facilities had a negative influence on consumer outlet choices in India. (Sinha and Banerjee 2004). Newman and Patel (2004) argued that store atmosphere is very critical determinant of retail store choice of customers. The design or the layout of retail store increases in-store experience of patrons (Hartman \& Spiro, 2005). Nice smells of fragrances increase the behavior of curiosity among customers (Orth \& Bourrain, 2005. Wirtz, Mattila, \&Tan, 2007).
\end{abstract}

\section{Location}

According to Mendes and Themido (2004), one important decision a retailer can make is where to locate a retail outlet; a retail store can prosper or fail solely based on its location. Research on retail patronage and store choice of shopping have been predicted by distance or location by many customers. (Leszczyc, Sinha \& Timmermans, 2000; Achen, 2005; Biba, Rosiers, Theriault, \& Villeneuve, 2006. As agured by Sinha and Banerjee (2004) concluded that store convenience and location positively influence consumer store selection. Goswami (2009) concluded that customer patronage to grocery stores was found to be positively related to location and negatively related to travel convenience. Brooks et al. (2001) explain that store choice is driven by location; hence large_Scale retailers often focus on a geographic position strategy. Additionally, Kwon and Lennon (2011) found that location is very prominent attributes for female shoppers when buying 
apparel brands. Terano, Yah, Mohamed and Saimin (2015) found location as a variable that influences retail outlet selection.

\section{Image}

Saraswat, Mammen, Aaja and Tewari (2010) defined store image as the symbolic, experiential expression of the manner in which consumers see or visualize a store. According to Du Preez, Visser and Van Noordwyk (2008) store image is the perceptions of consumers about a particular store. According to Prasad and Aryasri (2011) store image is an important factor in two types of decisions relevant to developments in retail markets; namely, consumer decisions (where and when to shop) and retailer decisions (when, where and how to operate their stores). In recent studies by scholarssuch as Kardes, Cline and Cronely (2011) and Lusch, Dunne and Carver, (2011) store image was defined simply as a set of attributes deemed important by consumers. Visser et al. (2006:61) emphasised that differences exist in the perceived prominence of retail store image amongst customers when making buying decisions. It's argued that retailer can build consumers' loyalty with a positive store image (Bloemer \& Odekerken-Schroder, 2002).

Consumer will evaluate whether the store image meets his expectations. ( Morschett et al, 2005)

\section{Price}

Price has always been a major factor when it comes to patronage of retail stores. (Monroe 2003) According to Hassan, Muhammad and Abu Bakar (2010) consumers tend to choose a store that offers reasonable prices. Customers who think that they have profit due to discounts promotions displayed more loyalty to the store (Grace \& O'Cass, 2005). Akinci et al. (2007) found that the most important factors that affect supermarket patronage in Istanbul are pricing, quality and waiting time at the cashier. Walters and Jamil (2003) price are associated with consumer specials search, which to affect patronage behavior. A study by Seiders and Tigert (2000) indicates that low prices are primary reasons for their format choice.

\section{Patronage}

Patronage is measured by comparing customer's total weekly/ monthly purchase from a store. Also, it is the average number of trips made in a given period of time. It relates to frequently purchased, low-value items like groceries, looks at number of items purchased and not its value as an indication of patronage behavior. According to (Pan and Zinkhan 2006) patronage is critical to retailers in order to direct their promotional program to the target that is likely to purchase. Customers are much powerful with more choice available to them through intense competitions; therefore, retail patronage is very important. (Hyman 2006). Pan and Zinkhan (2006) identified two dimensions of retail patronage predictors, and rank-ordered the predictors.: assortment, quality, store atmosphere, low price levels, convenient location, fast checkout, convenient opening hours, friendliness of salespeople, and convenient parking facilities.

\section{Link between attributes and retail outlet patronage}

Yilmaz et al., (2007) found location, product, price and quality, physical appearance, attitude of store staff as important factors influencing customer retail outlet selection choice. Besides, Morschettetal (2005) explained that product quality, assortment, price, location and atmosphere shape the choice of retail outlet selection. The results of Moore and Carpenter's (2006) study reveal that price, quality and selection of merchandise were ranked as the most important retail store attributes to male consumers when deciding upon a clothing store. Dhurup, Mafini and Mathaba (2013) examined store image as a factor which influences retail selection choice among consumers of sports apparel in South Africa on a total sample of 489 sportswear consumers in three shopping malls in Gauteng Province of South Africa. The study revealed a positive significant relationship between image and choice of outlet selection. In addition, Akinci et al. (2007) found pricing, quality and waiting time at the cashier as the most important factors that affect supermarket patronage in Istanbul.

Research on retail patronage and store choice of shopping have been predicted by distance or location by many customers. (Leszczyc, Sinha \& Timmermans, 2000; Achen, 2005; Biba, Rosiers, Theriault, \& Villeneuve, 2006.Pan and Zinkhan (2006) concluded that physical location, parking facilities, check-out speed, and store atmosphere are crucial for consumers searching for a retail store. Sirgy, Grewal, \& Mangleburg, (2000), in their study modeled relationships among store environment (including store atmospherics), store patron image, shoppers' self-concept, self-congruity, functional congruity, and retail patronage. Previous research by (Miranda, Konya \& Havrila, 2005; Sirgy, Grewal, \& Mangleburg, 2000), identified location of store, nature and quality of stocks, in-store promotions, sales personnel, physical attribute, and convenience of store, atmospherics and loyalty cards as multiple environmental constructs that influence that influence retail store patronage. Matiza and Oni (2014) studied 'The Salient Factors Influencing the Choice of Food Retail Outlet amongst First Year Students at a Rural-Based Tertiary Institution'. And they concluded that sensitive price of goods was the key influencer for students.

As argued by Broekemier, Marquardt and Gentry (2008), retail patronage intentions have been found to be more highly correlated with consumers' beliefs about the image of a retail service environment than with the merchandise quality, general price level and product selection.

Pan and Zinkhan (2006) highlighted the following retail environment factors: physical location, parking facilities, checkout speed, and store atmosphere as crucial for consumers searching for a traditional retail store. Contrary, Sinha and Banerjee (2004) found entertainment, parking and ambience facilities as negative influence on consumer outlet choices in India.Based on reviewed literature conceptual frame work was designed 


\title{
Conceptual frame work of the study
}

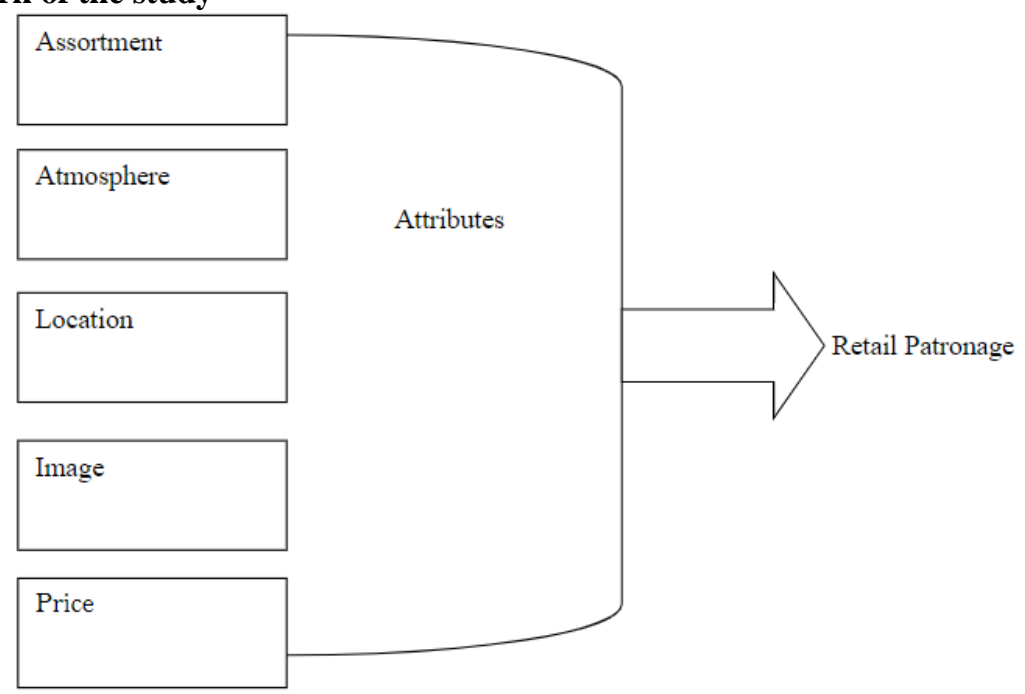

Fig 1: Link between attributes and retail outlet patronage (Author's Construct 2015)

\author{
Research Hypotheses \\ H1: There is a significant impact of Assortment and retail patronage \\ $\mathrm{H} 2$ : There is a significant impact of Atmosphere and retail Patronage \\ H3: There is a significant impact of Location and retail Patronage \\ H4: There is a significant impact of image and retail Patronage \\ H5: There is a significant impact of Price and retail patronage
}

The research hypothesis was as a result of literature reviewed and conceptual frame work.

\section{Problem of the study}

The researcher intercepted a report made in Economic Tribune published by My joy on line.com on $21^{\text {st }}$ January 2013 under the caption' Accra Mall shop owners unhappy with low patronage. The Economic Tribune revealed that about 30 percent of the shop owners enjoyed healthy sales over the past two years while the remaining seventy percent struggle to meet their target. This report initiated the study to look into what retail store could also do in their own way to influence patronage.

\section{Methodology}

Both primary and secondary data were employed to solicit solution to the problem of the study. The study adopted purposive sampling technique to select Retail stores whereas convenience sampling techniques were employed to select a retaill customer. The suitable sampling technique for this study is non-probability technique using convenience sampling. This is due to the difficulty in determining the specific list of customers.

\section{1- Participants}

The target population comprised various Retail customers, both sexes between the ages of 18 and 50 who visited Melcom (MC), Shoprite (SP) Mr. Price (MP). Max Mart (MM). Game Discount (GD), Great wall (GW) and Koala (KA) all in the Greater Accra Region during the period of May and June 2013. Selected customers were randomly interviewed at different times of the day, on every day of the week, over a four-week period. A sample of 309 customers returned the questionnaires out of 500 questionnaires sent out.

\section{2-Data collection and Data analysis}

Data were collected through the use of a structured questionnaire. The questionnaire was divided into seven sections. Section A elicited general and biographical information about respondents. Section B elicited information on Assortment. Section C sought information on Atmosphere. The questions in Section D elicited information on Location. The section E sought information on Image. The questions in Section F elicited information on Price and Section $G$ elicited information on Patronage. Likert scales anchored by strongly disagree (1) and strongly agree (5) were used in the questionnaire.

Once the data is collected and entered to computer using SPSS. The following statistics were used: descriptive statistics in order to have clear picture of study variables. Cranach's alpha, which measures the internal consistency of a construct, Kurtosis and Skewness values were used to check the normality of each variable used in the research. Chi square analysis was used to measure the effect of independent variable on dependent variable 
Results and Analysis

Table 1. Descriptive information

\begin{tabular}{lll} 
Variables & Frequency & Percentage \\
\hline Gender & 160 & 51.8 \\
Female & 149 & 48.2 \\
Male & 309 & 100.0 \\
Total & 121 & \\
\hline Ages & 139 & 39.2 \\
$18-28$ & 49 & 45.0 \\
$29-39$ & & 15.8 \\
40-50 & 72 & \\
\hline Retail Stores & 67 & 23.3 \\
Melcom & 27 & 21.7 \\
Shoprite & 31 & 8.7 \\
Mr. price & 32 & 10.0 \\
Max mart & 27 & 10.3 \\
Game discount & 29 & 8.7 \\
Ghana Grocery & 24 & 9.3 \\
Great wall & & 8.0 \\
Koala & 113 & \\
\hline No. of Visit & 107 & 36.5 \\
Below 5 times & 89 & 34.7 \\
Between 6 to 10 & & 28.8 \\
More than 11 & &
\end{tabular}

\section{Survey Results, 2015}

The results shown in Table 1 indicate that $51.8 \%$ of the respondents are females while $48.2 \%$ are male. $42.1 \%$ of the modal age is between 29-39. The highest patronized store is Melcom at 23.3\%. Also 36.5. \% Of the respondent had visited a particular retail store below 5 times,

Table 4. Values of Cronbach's alpha for the research construct

(Source; Author's compilation)

\begin{tabular}{|l|l|}
\hline Constructs & Values \\
\hline Assortment (A) & 0.654 \\
\hline Atmosphere (AT) & 0.575 \\
\hline Location (L) & 0.623 \\
\hline Image (I) & 0.821 \\
\hline Price (P) & 0.932 \\
\hline Retail patronage (RP) & 0.873 \\
\hline
\end{tabular}

A reliability test was carried out using Cronbach's alpha, which measures the internal consistency of a construct. The recommended minimum acceptable limit of reliability measure, as reported by (U. Sekaran, 2003) is 0.60 . As shown in Table 4, all the constructs passed the reliability test.

Table 5. Descending means of the attributes of retail outlet

\begin{tabular}{|l|l|l|}
\hline Attributes & Mean & Standard Deviation \\
\hline Assortment & 4.21 & 0.45 \\
\hline Atmosphere & 4.23 & 0.67 \\
\hline Location & 4.00 & 0.79 \\
\hline Image & 4.11 & 0.89 \\
\hline Price & 4.01 & 0.72 \\
\hline
\end{tabular}

(Source; Author's compilation)

The result shown in Table 5 indicates frequency and descriptive statistics used to determine the relative importance of each of the constructs. The competitive priorities shown in Table 5 have a mean above 4 . Therefore, it concludes that all of constructs are of significant importance to the study. 
Table 6. Skewness and Kurtosis for research constructs. Variable

(Source; Author's compilation)

\begin{tabular}{|l|l|l|}
\hline Attributes & Skewness & Kurtosis \\
\hline Assortment & 4.00 & -0.32 \\
\hline Atmosphere & 4.20 & -0.21 \\
\hline Location & 4.01 & 0.12 \\
\hline Image & 4.12 & 0.54 \\
\hline Price & 4.21 & -0.34 \\
\hline
\end{tabular}

From Table 7, Kurtosis and Skewness values were used to check the normality of each variable used in the research. Skewness values larger than $(+1)$ or smaller than $(-1)$, as suggested by Hair, Babin, Money and Samouel (2003) indicate a substantially skewed distribution. Besides according to Hair, Anderson, Tatham, and Black (1998) added that a curve is too peaked when the Kurtosis exceeds $(+3)$ and is too flat when it is below $(-3)$. This means Skewness values within the range of $(-1)$ to $(+1)$ and Kurtosis values within the range of $(-3)$ to $(+3)$ indicate an acceptable range. As shown in Table 5, the values of Skewness and Kurtosis for each variable indicate that the research constructs fell within the acceptable range.

\section{Analysis of impact of Assortments on retail patronage}

Table 1

\begin{tabular}{|l|l|l|l|l|}
\hline & Calculated value & Df & Asymp.(sig 2tail) P & Table value \\
\hline Pearson's chi- square & $14.34(\mathrm{a})$ & 5 & 0.002 & 4.22 \\
\hline
\end{tabular}

Source: Author's compilation

Ho: There is no significant impact of assortment on retail patronage. H1: There is a significant impact of assortment on retail patronage

Inference: At 5\% level of significance, $\mathrm{P}=0.002$.therefore $\mathrm{P}$ value is less than 0.05 . Hence, Ho is rejected; therefore, there is a significant impact of assortment on retail patronage.

\section{Analysis of impact of Atmosphere on retail patronage}

Table 2

\begin{tabular}{|l|l|l|l|l|}
\hline & Calculated value & df & Asymp,(sig 2tail) P & Table value \\
\hline Pearson's chi- square & $14.34(\mathrm{a})$ & 5 & 0.001 & 6.74 \\
\hline
\end{tabular}

Source: Author's compilation

Ho: There is no significant impact of atmosphere on retail patronage. H2: There is a significant impact o of atmosphere on retail patronage

Inference: At 5\% level of significance, $\mathrm{P}=0.001$.therefore $\mathrm{P}$ value is less than 0.05 . Hence, Ho is rejected; therefore, there is a significant impact of atmosphere on retail patronage.

\section{Analysis of impact of Location on retail patronage}

Table 3

\begin{tabular}{|l|l|l|l|l|}
\hline & Calculated value & df & Aymp,(sig 2tail) P & Table value \\
\hline Pearson's chi- square & $15.12(a)$ & 3 & 0.001 & 3.45 \\
\hline
\end{tabular}

Source: Author's compilation

Ho: There is no significant impact of Location and retail patronage H3: There is a significant impact of Location on retail patronage.

Inference: At 5\% level of significance, $\mathrm{P}=0.001$.therefore $\mathrm{P}$ value is less than 0.05 . Hence, Ho is rejected; therefore, there is a significant impact of Location on retail patronage.

\section{Analysis of impact of image on retail patronage}

Table 4

\begin{tabular}{|l|l|l|l|l|}
\hline & Calculated value & df & Asymp, (sig 2tail) $\mathrm{P}$ & Table value \\
\hline Pearson's chi- square & $11.52(\mathrm{a})$ & 5 & 0.001 & 7.32 \\
\hline
\end{tabular}

Source: Author's compilation

Ho: There is no significant impact of image on retail patronage. H1: There is a significant impact of image and retail patronage. 
Inference: At 5\% level of significance, $\mathrm{P}=0.001$.therefore $\mathrm{P}$ value is less than 0.05 . Hence, Ho is rejected; therefore, there is a significant impact of image on retail patronage

\section{Analysis of impact of Price on retail patronage}

Table 5

\begin{tabular}{|l|l|l|l|l|}
\hline & Calculated value & df & Asymp,(sig 2tail) P & Table value \\
\hline Pearson's chi- square & $15.31(\mathrm{a})$ & 5 & 0.002 & 7.00 \\
\hline
\end{tabular}

Source: Author's compilation

Ho: There is no significant impact of Price on retail patronage. H1: There is a significant impact of Price and retail patronage.

Inference: At 5\% level of significance, $\mathrm{P}=0.002$.therefore $\mathrm{P}$ value is less than 0.05 . Hence, Ho is rejected; therefore, there is a significant impact of Price on retail patronage

\section{Discussion}

The Chi-square analysis shows the existence of a significant impact between each of the five independent variables (Assortment, Atmosphere, Location, Image, and Price) on dependent variable (retail patronage). These results are congruent with the findings of previous empirical work of (Polat and Kulter 2007; Yilmaz et al., 2007; Duman \& Yagci, 2006) established that product diversity, product quality, inner atmosphere and appearance, quick shopping facility, attitude and interest of staff and prices of goods contribute to retail store patronage. This is supported by Duman and Yagci (2006) who discovered that customers' patronage intentions are affected by value perception, product quality perception, service quality perception, discount perception and comparable price perception.

Whiles Cronin et al., (2000) concluded that safe shopping environment constitute to patronage. In addition to the foregoing, Grewal et al., (1998a) found special discounts and promotion to increase customers' interest toward the supermarket. Previous research suggests a retailer can build consumers' loyalty with a positive store image (Bloemer $\&$ Odekerken-Schroder, 2002). Indian consumers were also found to be price sensitive and quality conscious (Tuli $\&$ Mookerjee, 2004). In their own study, Akinci et al. (2007) found that the most important factors that affect supermarket patronage in Istanbul are pricing, quality and waiting time at the cashier. However, Sinha and Banerjee (2004) found entertainment, parking and ambience facilities as negative influence on consumer outlet choices in India

\section{Recommendations}

Retail stores must have easily readable signs available to enable customers find products or items easier. Complementary or related product categories should be found together. Customers would not patronize stores they find difficulties finding some items inside the store because store signage was poor. Management of Retailers stores should design store environments that reduce the expected shopping difficulties of customers (Gutierrez, 2004).

Store personnel dressed in uniforms at vantage point should be available to help customers look for items or respond friendly and helpful manner to product information questions of the customers. It is also necessary to improve upon the general store environment. Supermarket that does not have an air conditioning system, it needs to improve on its sanitation and incidence of dusty items. Retail store must improve lighting system. As mentioned by Wilson (2006) that retail store managers must focus on what matters most to the customers. From dressing rooms for clothing stores the lighting, restrooms, attitude of sales associates and the overall condition such as cleanliness.

Managers must educate the customers on the information they need to make the purchase whiles making customers life better in the shop by having newspapers available in the shop, able to check their mails entertain customers by showing live football matches or current news of well renowned broadcasting houses such as CNN, BBC and others. A retail store should establish automated teller machines (ATMs), repair shops, drug stores, etc (Cohen, 2006).

\section{Conclusion}

One key success in managing a retail store is to understand store patronage behavior of your customers. It is always necessary for managers to know which outlet attributes are important in attracting the requisite traffic for success.

\section{Limitation of the study}

The decision about the size of the sample was taken considering time and cost, the need of precision and a variety of further considerations. Due to the limit of time and costs, the population was narrowed to retail customers in Greater Accra alone. This study is also limited to few retails store attributes, other existing attributes were excluded in the study due to time constraints.

\section{References}

[1].Akinci, E. D., Bacanli, S. \& Kiroglu, G.(2007). Adaptive conjoint analysis and application on istanbul discount markets. Journal of Dogus University, 8,1-11.

[2].Batt, P.J. (2009). Factors influencing the consumer's choice of retail store. Curtin Business School, Curtin University of Technology,Australia.

[3].Biba, G; Rosiers, F. D; Theriault, M; \& Villeneuve, P (2006). Big boxes versus traditional shopping centres: Looking at households' shopping trip patterns. Journal of Real Estate Literature, 14(2). 
[4].Bloemer, J. \& Ruyter, K. D. (1998). On the relationship between store image, store satisfaction and store loyalty. European Journal of Marketing,32,499-513.

[5].Broekemier, G., Marquardt, R. \& Gentry, J.W. (2008). An exploration of happy/sad and liked/disliked music effects on shoppingintentions in a woman's clothing store service setting. Journal of Service Marketing, 22(1), 59-67.

[6].Cox, R. \& Brittain, P. (1996). Retail Management, 3rd Ed. Hong Kong: Pitman Publishing

[7].Danziger, Shai, and Ruthie Segev (2006), "The Effects of Infor-mative and Non-informative Price Patterns on Consumer PriceJudgments," Psychology and Marketing, 23 (June), 535-53.

[8].Dhurup. M Mafini.C and Mathaba R (2013) Store Image Factors Influencing Store Choice among Sportswear Consumers:Baseline Findings from South Africa Mediterranean Journal of Social Sciences Vol 4 No 14 November

[9].Gutierrez, B. (2004). Determinants of planned and impulse buying: The case of the Philippines. Asia Pacific Management Review, 9(6), 1061-1078.

[10]. Gutierrez, B. (2008). In-store media: How effective are they? Evidence from the Philippines. Philippine Management Review, 15(1), 65-82.

[11]. Grace, D., O"cass, A. (2005). An examination of the antecedents of repatronage intentions across different retail store formats. Journal of Retailing and Consumer Services, 12,227-243

[12]. Hassan, Y., Muhammad, N. M. N., \& Abu Bakar, H. (2010). Influence of Shopping Orientation and Store Image on Patronage of Furniture Store. International Journal of Marketing Studies, 2(1), 175-184.

[13]. Hyman, R. (2006, April 6). Savvy shoppers are calling the shots in a cost sensitive world. Marketing Week, 37.

[14]. Jobber, D. (2009). Principles and practice of marketing: England, McGraw-Hill Publishing Company.

[15]. Hair J, Babin .B, Money, A and Samouel.P (2003) "Essentials of Business Research Methods," Lehigh Publishing.

[16]. Hair.J ,Anderson.R ,Tatham. R and Black. W (1998) "Multi- variate Data Analysis," 5th Edition, Prentice-Hall, Upper Saddle River, 1998.

[17]. Kaura, V (2012), 'A Link for Perceived Price, Price Fairness and Customer Satisfaction', PacificBusiness Review International Journal, Volume 5, No. 6

[18]. Matiza. T and. A. Oni (2014) The Salient Factors Influencing the Choice of Food Retail Outlet amongstFirst Year Students at a Rural-Based Tertiary Institution Mediterranean Journal of Social

[19]. Mendes, A. B. and I.H. Themido. 2004. multi-outlet retail site location assessment. International Transactions in Operational Research.11, pp. 1-18. Retrieved February 2, 2007, EBSCOhostdatabase.

[20]. Miranda, M. J.,Kónya, L. \& Havrila, I.(2005). Shoppers' satisfaction levels are not the only key to store loyalty. Marketing Intelligence and Planning, 23,220-232

[21]. Monroe, Kent B. (2003), Pricing: Making Profitable Decisions,3rd ed., Boston: McGrawHill/Irwin

[22]. Morschett,D.,Swoboda,B.,Schramm. Klein,H.,(2005),"Perception of store attributes and overall attitude towards grocery retailers: The Role of shopping motives", The International Review of Retail, Distribution And Consumer Research,15(4),pp.423-447

[23]. Muzondo N. \& Mutandwa, E. (2011). The seven P's of marketing and choice of main grocery store in a hyperinflationary economy.Contemporary Marketing Review, 1(9), pp1-18.

[24]. Oghojafor, B.E.A., Ladipo, P.K.A., \& Nwagwu, K.O(2012). Outlet Attributes as Determinants of Preference of Women between a Supermarket and a Traditional Open Market. American Journal of Business and Management Vol. 1, No. 4, 2012, 230-240

[25]. Pan, Y. \& Zinkhan, G. (2006). Determinants of retail patronage: A meta-analytical perspective. Journal of Retailing, 82(3), 229-243.

[26]. Saraswat, A., Mammen, T., Aagja, J.P. \& Tewari, R. (2010). Building store brands using image differentiation. Journal of IndianBusiness Research, 2(3), 166-180.

[27]. Sekaran. U. (2003), "Research Methods for Business: A Skill Building Approach," 4th Edition, John Wiley and Sons, New York.

[28]. Sinha, P K, \& Banerjee, A. (2004). Store choice behaviour in an evolving market. International Journal of Retail and Distribution Management, 32(10),.482-

[29]. Sirgy, M.J., Grewal, D., \& Mangleburg,T (2000). Retail environment, self-congruity, and retail patronage: An integrative model and a research agenda, Journal of Business Research 49, 127-138

[30]. Sirgy, Grewal, \& Mangleburg, (2000), in their study modeled relationships among store environment (including store atmospherics), store patron image, shoppers' self-concept, self-congruity, functional congruity, and retail patronage.

[31]. Smith PR, Taylor J (2005). Marketing Communications: An Integrated Approach, Kogan Page India, London.

[32]. Tuli, R. \& Mookerjee, A. (2004). Retail formats: Patronage behavior of Indian rural consumers. South Asian Journal of Management; 11(3),57-73.

[33]. Uslu, S. (2005). The reasons that shopping mall preferences of consumers. Marketing World,19,54-63.

[34]. Walters, R.G \& Jamil, M (2003). Exploring the relationships between shopping trip type, purchases of products on promotion, and shopping basket profit, Journal of Business Research, 56(1), 17-29.

[35]. Wilson, M. (2005, September). Shopping: It's all in the details. Chain Store Age, 81(9), 11

[36]. Visser, E., Du Preez, R. \& Van Noordwyk, H.J. (2006). Importance of apparel store image attributes: perceptions of female consumers. South African Journal of Industrial Technology 32(3):49-62.

[37]. Yilmaz, V., Aktas, C. \& Celik, H. E. (2007). Development of a Scale for measuring consumer behaviour in store choice. Anadolu, University Journal of Social Sciences, 7, 171-185. 